\title{
A postmodern perspective regarding older adults' oral health
}

\author{
Uma perspectiva pós-moderna sobre a saúde bucal de idosos
}

Alexandre Favero Bulgarelli (https://orcid.org/0000-0002-7110-251X) ${ }^{1}$

Fabiana Costa Machado Zacharias (https://orcid.org/0000-0003-1150-6114) ${ }^{2}$

Soraya Fernandes Mestriner (https://orcid.org/0000-0002-7482-8041) ${ }^{3}$

Ione Carvalho Pinto (https://orcid.org/0000-0001-7541-5591) ${ }^{2}$
${ }^{1}$ Programa de PósGraduação em Saúde

Coletiva, Universidade Federal do Rio Grande do Sul. R. São Manoel 963/107, Rio Branco. 90620-110 Porto Alegre RS Brasil. alexandre.bulgarelli@

ufrgs.br

${ }^{2}$ Programa de Pós-

Graduação em Enfermagem em Saúde Pública,

Universidade de São Paulo.

Ribeirão Preto SP Brasil.

${ }^{3}$ Faculdade de Odontologia

de Ribeirão Preto, USP.

Ribeirão Preto SP Brasil.

\begin{abstract}
This article aims to comprehend meaning assigned to oral health, by means of older adults discourses, supported by a Social Constructionist perspective. This is a qualitative study with a descriptive and comprehensive design based on the Social Constructionism theoretical support conducted by means of interviews with 19 older adults. Data were analysed by means of a Discourse Analysis with identification of Interpretative Repertoires, which structured the meanings proposed to oral health. It were created repertories to disclosure possible meanings assigned to the oral health by older people as: having a clean mouth; having good comprehensive/general health; having a beautiful smile and oral health well-being condition; and suffering in the past and accepting pain. The meaning assigned to oral health by older people, in a social constructionist perspective, allow us to comprehend the subjectivity behind oral health of older people, which can guide health professionals' approaches to deal with it.
\end{abstract}

Key words Aged, Dental care for aged, Public health, Qualitative research, Social perception
Resumo O objetivo deste artigo é compreender o significado da saúde bucal, por meio de discursos de idosos, com apoio da perspectiva teórica Construcionista Social. Trata-se de um estudo qualitativo com um desenho descritivo e compreensivista, baseado no referencial teórico do Construcionismo Social realizado por meio entrevistas com 19 idosos. Os dados foram analisados por meio de uma Análise de Discurso com identificação de Repertórios Interpretativos, que estruturou os significados atribuídos à saúde bucal. Foram criados repertórios para a compreensão de significados possiveis atribuídos à saúde bucal por pessoas idosas. Deste modo, saúde bucal é: ter uma boca limpa; ter boa saúde geral; ter um sorriso bonito e se sentir bem com a condição bucal; ter tido algum sofrimento no passado aceitando a dor. Os significados atribuídos à saúde bucal pelos idosos, numa perspectiva construcionista social, nos permite compreender a subjetividade por trás da saúde bucal das pessoas idosas na atualidade, o que pode orientar as abordagens dos profissionais de saúde para lidar com isso.

Palavras-chave Idosos, Cuidados dentários para idosos, Saúde pública, Pesquisa qualitativa, Percepção social 


\section{Introduction}

The increase in older people population is a major challenge for global public dental health and community dental health services. Currently, comprehension of subjectivities behind the older adult oral health is a challenge for health researchers worldwide, which includes dentists from the Brazilian Unified System (Portuguese Acronym is SUS). This Brazilian public health system is based on national policies which offer a comprehensive assistance to older people including dental treatment and oral health care.

Older adult oral health needs are associated with various aspects like physiological conditions, life and medical history, resilience, interpersonal relationships, social, cultural and economic factors and access to dental treatment ${ }^{1,2}$. To older people, dental literacy and oral health beliefs are socially constructed and reconstructed during their lives, by means of social interactions expressed in their speeches. It means that oral health can be comprehended as a social creation portraited in older people narratives. Narratives and speeches can indicate human's perception regarding health. Analysing daily narratives and speeches allow us to comprehend meanings attributed to objects, interpersonal relations and social phenomena ${ }^{1,3,4}$. To this study, we comprehend oral health as a social phenomenon.

Based on this assumption, we can observe that meanings regarding oral health surround a social construction based on older people social interactions. This process is full of different social practices and within different cultures, which emerges in different epidemiological, demographic contexts, and social determinants ${ }^{5,6}$. These facts can bring out descriptions of older adult access to oral health treatment, life history and the sociocultural context in which they lived ${ }^{1}$. This emerges in a discursive relationship that is interactively established between people and their discourses ${ }^{3,7}$.

The research question is: what meanings can we construct with older people regarding their oral health? Therefore, we aimed to construct and comprehend meanings assigned to oral health, by means of older adults' discourses, in a current postmodern comprehension.

\section{Methods}

This is a qualitative study sustained by means of the postmodern Social Constructionism theoret- ical perspective ${ }^{8-10}$. Social Constructionism is a theory of knowledge which can scientifically support the construction of oral health meanings. It shows that perceptions of a social reality or a phenomenon, are constructed by individuals' interactions. These interactions can be expressed and observed by means of the language used by people in daily conversations, speeches and narratives 9 . We interviewed 19 active, independent and socialized older adults, users of SUS in the city of Ribeirão Preto/SP, Brazil. All the older people interviewed to this research were users of primary healthcare services offered by means of five Family Health Centres within SUS. We collected data, during the first semester of 2010, through semi structured interviews which were audio recorded by means of the Sony Monodigital Voice Recorder with PC Link ICD/PX333 Series. We used semi structured interviews because this allowed us to achieve information regarding the research object during a semi structured conversation started by means of triggering questions ${ }^{11}$. One $\mathrm{PhD}$ researcher interviewed the elderly in their homes in previously scheduled days. The interviews had an average of 42 minutes each, followed some trigger questions (Chart 1), and had a detailed transcription $^{12}$. The amount of participants was achieved by means of saturation of data ${ }^{13}$. Older people who were interviewed, comprised a group that met the following criteria: no signs of dementia nor mentally unfit (Cut off point was 26,5 according to Mini Mental State Examination) ${ }^{14}$; 5-8 years of study; 65-up years old; physically independent; and consented to freely participate in the research.

We performed a Discourse Analysis as follows: 1 - construction of the textual material of analysis ${ }^{9}$ through the interview transcripts that recorded all verbal participation of the respondents; 2 - intense and reflective reading of the written material to comprehend older people narratives; 3 - identification of the Interpretative Repertoires and excerpts of the material; 4 - discussion of these Interpretative Repertories with fragments of narratives and the literature, within the historical events and social interactions experienced by older people; 5 - written presentation of the analytical process, results and discussion.

We analysed the participants' social interaction and experiences with dental care constructed during their lives. Furthermore, the relation between Brazilian health policies and historical dental care and treatment to older people allowed us to identify the Interpretative Repertoires $^{3,9,10}$. These Interpretative Repertoires are 
Chart 1. Questions used to perform the semi structured interviews with Brazilian older people. Unified Health System(SUS), Brazil, 2017.

\begin{tabular}{|l|l|}
\hline \multicolumn{1}{|c|}{ Triggering Questions } & \multicolumn{1}{c|}{ Issues } \\
\hline Do you think dental aesthetics is important in your current life? & Aesthetic \\
\hline $\begin{array}{l}\text { Did you suffer with any dental or oral situation in your life? Please, tell } \\
\text { me something about. }\end{array}$ & Pain \\
\hline Do you brush your teeth or clean your prosthesis frequently? Why? & Oral Hygiene \\
\hline If your grandson askes you about oral health, what would you say to him? & Perceptions regarding oral heath \\
\hline $\begin{array}{l}\text { Does the mouth means the same thing as other organs to you? Can you } \\
\text { tell me why? }\end{array}$ & Comprehensive health \\
\hline
\end{tabular}

linguistic figures identified in the older people narratives, which characterized the experienced phenomenon in association with the research object. These linguistic figures are instruments of the Social Constructionism theoretical support that arise in the researcher interpretation ${ }^{9,10}$.

It was a study developed with Brazilian people and the speeches and narratives were recorded in Portuguese. To avoid losses of potential meanings with the translation we performed a back-translation process with an English linguistics expertise $\mathrm{e}^{15,16}$. We used a Brazilian researcher (co-author) as moderator in cooperation with a professional English translator. During the 9-hours back-translation, the moderator explained to the translator the intended meaning and its context in the Portuguese language within the older people narratives and speeches.

This study is part of the research modality of minimal risk, which was approved by the Research Ethics Committee of the Health Centre of the School of Medicine at Ribeirão Preto, University of São Paulo. It should be noted that permission of older people was an imperative aspect for participation in the study. All participants authorized the publication of their narratives by signing the consent form. The anonymity was ensured.

\section{Results and discussion}

In a descriptive process to start the data analysis we observed that most participants were women (65-75 years old), less than five years of schooling self-reporting 'neither good or bad' oral health conditions. To illustrate it was possible to observe that older men refer more pain and suffering as meaning of oral health. And older women refer comprehensive health, aesthetic and well-being as meanings for oral health (Table 1). We did not discriminate gender to analyse data because the aim was to construct the older people' voice regarding oral health meanings.

The meaning attributed to oral health comprises categories like satisfaction with the dental condition; aesthetics; resilience; comprehensive care and dental hygiene. Furthermore, the construction of oral health meaning is associated with figures of speech. These figures of speech are perceptible in the narratives of older people and the major findings show that meanings regarding oral health are: cope with toothache; cleanness of mouth and teeth; good general health and a beautiful smile.

This is the first study in which a qualitative scientific research attempts to propose a Social Constructionism perspective to comprehend and construct possible meanings regarding oral health with the participation of older people. It is a postmodern perspective approaching oral health scientific researches and qualitative methodologies. The findings of this study are important because it suggested that the social construction of oral health are implicit in the real lives of older people regarding a moderate/neither bad or good perception of their oral health. Older adult under vulnerability, which is a currently social reality for an important number of older people in Brazil, use more the oral health at SUS ${ }^{17}$. These older people report a moderate self-perception of oral health and this is another social postmodern reality ${ }^{18,19}$. Primary health care, within a public health service, can structure the meaning of oral health in accordance with the realities of older people in different environment and social situations $^{1,9,10,20}$. To Social Constructionism, the primary health care has a dialogical context where the service user encounter space to talk and discuss about health with health professionals ${ }^{7}$. Furthermore, sharing experiences and talking about oral health is a potential instrument to construct 
Table 1. Description of oral health meanings perceived by means of Brazilian older people. Unified Health System, Brazil, 2017.

\begin{tabular}{|l|l|c|c|c|r|r|}
\hline \multicolumn{2}{|c|}{ Oral Health meanings } & $\begin{array}{c}\text { Not only } \\
\text { teeth } \\
\text { cleaning }\end{array}$ & $\begin{array}{c}\text { Comprehensive } \\
\text { health }\end{array}$ & $\begin{array}{c}\text { Beautiful smile } \\
\text { and a well-being } \\
\text { condition }\end{array}$ & $\begin{array}{c}\text { Pain and } \\
\text { suffering }\end{array}$ & Total \\
\hline \multirow{2}{*}{ Age } & $65-75$ & $20 \%$ & $30 \%$ & $43 \%$ & $7 \%$ & $12(75 \%)$ \\
\cline { 2 - 7 } & $76 \leq$ & $6 \%$ & $10 \%$ & $24 \%$ & $60 \%$ & $3(25 \%)$ \\
\hline \multirow{2}{*}{ Gender } & Men & $18 \%$ & $10 \%$ & $18 \%$ & $54 \%$ & $8(42 \%)$ \\
\cline { 2 - 7 } & Women & $29 \%$ & $12 \%$ & $47 \%$ & $12 \%$ & $11(58 \%)$ \\
\hline \multirow{2}{*}{$\begin{array}{l}\text { Self-reported } \\
\text { oral health }\end{array}$} & Good & - & $15 \%$ & $85 \%$ & - & $4(22 \%)$ \\
\cline { 2 - 7 } & Neither good or bad & $17 \%$ & $20 \%$ & $60 \%$ & $3 \%$ & $9(47 \%)$ \\
\cline { 2 - 7 } & Bad & $9 \%$ & $10 \%$ & $32 \%$ & $49 \%$ & $6(31 \%)$ \\
\hline \multirow{2}{*}{\begin{tabular}{l} 
Schooling \\
\cline { 2 - 7 }
\end{tabular}} & 5 years & $7 \%$ & $14 \%$ & $17 \%$ & $62 \%$ & $13(68 \%)$ \\
\cline { 2 - 7 } & 5 years & 30 & $16 \%$ & $10 \%$ & $34 \%$ & $6(32 \%)$ \\
\hline
\end{tabular}

meaning regarding health ${ }^{21}$. Therefore, construction of meaning is an observation of the relationships which indicates arguments of a phenomenon ${ }^{3}$.

The first aspect of analysis appeared when one interviewee described the process of cleaning dentures and/or teeth as part of comprehensive care for the body health. The narratives of older people are filled with experience and ordinary knowledge, which came from a historical and political moment in Brazil in which health was not a constitutional right and access to oral health services was not universal. Access to the oral health service can be related to the satisfaction with oral health. In Brazil, political and historical events, as the construction and implementation of current National Oral Health Policy and National Primary Care Policy, made a difference in the process of construction of the meaning of health ${ }^{1}$. It is important to highlight that these policies historically spread access to primary care services to the Brazilians and introduced the oral and dental services to the public health system regarding all complexity levels of care. In other words these events promoted better oral health conditions during the last decades reflecting in the current meaning attributed to the oral health ${ }^{1,22,23}$.-

The first interpretative repertoire that we constructed is Oral health is not only teeth cleaning. This repertoire shows the narrow relationship between oral health care, which is naturally incorporated in the whole-body hygiene, and comprehensive health care. This is something socially constructed by this group of older people by means of accessing health care information at a community health service. The way older people find out about their health can be relat- ed to primary care services. It is a service where older people access information and have essential treatment to oral health ${ }^{8,24}$. In Brazil this is something that happens according to health promotion actions which were develop in the city, among others, where the research was developed $^{25}$. These interviewees incorporate the hygiene of teeth and mouth into their lives and pointed it out as a daily task, conferring a meaning of oral health associated to whole-body hygiene and care.

'Hum... I take care of my heart... blood pressure... I brush my teeth... these things that are already something I do automatically... I get up in the morning... wash my face, brush my teeth, put on sunscreen, this is a routine. I do it automatically. Because I think it's very important... and to take care of the rest of my body I go to the doctor... to check if everything is well... isn't it? (Speech by participant $1 ; 71$ years old).

There is a perception of the dental hygiene as a normal daily activity. This fact is noticeable through the performative language present in the discourses about tooth brushing. In other words, with a Social Constructionism perspective, the speech indicates current actions as oral health care $^{8-10}$. This speech leads us to understand that tooth brushing is a process that is performed naturally. It is a process that became part of the daily ritual of these older people during their lives. This finding corroborates the significance of oral health as a hygiene process ${ }^{26}$. In addition to this aspect, hygiene habits are a process incorporated into the everyday practices because tooth brushing has the same value as other health care. Toward this fact, we can understand the similar importance attributed to the teeth, heart and skin. 
Oral health care for older people is categorized as a phenomenon associated with quality of life, tooth brushing, presence of a higher number of teeth and more visits to the dentist ${ }^{27}$. The act of comparing the care of the oral cavity with the body hygiene in maintaining a good quality of life and placing them in the same category of general health care was present within another narrative, such as in the following speech by another participant:

'I don't understand well but I think so... in my mind, the health of the mouth... if I'm taking care of the mouth, I'm taking care of the body... because on the outside you care... shower correctly... take good care... dry well... now inside, it is care for the mouth, I think inside... by taking care of the mouth, I'm taking care of the inside, right ... we swallow, don't we? (Speech by participant 2; 69 years old).

Health care is present in older people narratives and shows that the hygiene of the mouth is important as the whole-body hygiene ${ }^{27}$. People's values and attitudes are legitimated in their beliefs and truths $s^{3,7}$. Indeed, older people's beliefs, values and daily attitudes somehow guide their oral health care. This fact allows a constant negotiation of oral health care in association to their cultural, social and historical realities. This is related to a good quality of life ${ }^{8,9}$. This constant negotiation between aged people oral health and quality of life exist in a cyclical and self-renewing interaction between the relevance and impact of oral health in their everyday life ${ }^{27}$.

As older people describe their daily oral hygiene practices, they make a description of several actions that lead to different forms of acting in the world ${ }^{9}$. For the participants of this study, oral health becomes legitimated as general health in the act of whole-body hygiene. This fact leads to comprehend the role that oral health plays in the lives of these study participants. Thus, we constructed and named another interpretative repertoire which is Oral health is comprehensive health.

'So... I think that for example... sometimes we have bad teeth... a headache arises... sometimes the stomach hurts... I think that oral health represents everything... the mouth is everything... (the interviewee indicates with his hand, as if he was bringing food to the mouth)... Got it?... all because we eat... speak... talk... the mouth is on the face and is the first thing that people see... when we talk... got it now?' (Speech by participant 9; 73 years old).

Oral health meaning is related to different contexts in their lives, such as nutrition and social relationships. Thus, this speech had the dialogical function of integrating oral health as part of the whole, comprising physical, emotional and social aspects. Older adults might show different values to oral health, which are related to different meanings regarding general health ${ }^{28}$. Oral health is essential in the emotional and social life of people and also in the positive self-perception when facing oral health problems and needs $s^{7,21,28,29}$.

The meaning regarding oral health is the symbol of the mouth as an organ present in the 'front' of face that needs to be cared for. This organ is associated with appearance. In other words, proper oral health has the sense of indicating a healthy appearance and allowing for a good social relationship. Healthy mouth promotes conversation and verbalization of people beliefs. Therefore, being pleased with one's own appearance is an important aspect and expectation within relationships that allow for the construction of the meaning regarding oral health. Sometimes, sharing personal positive expectation and dental well-being are components to construct the meaning of oral health to older people ${ }^{28,29}$.

'I would talk to people... people who take care of their mouth is health caring... someone who takes care of the mouth cares for health... isn't that right?... who has a good mouth has health... this is true... if I take care of the health of the mouth, I chew, I talk, I show a smile to people with whom I relate' (Speech by participant 4; 64 years old).

For any human relationship, it is necessary to talk and smile, and these are social performances that are permanently related to actions and emotions ${ }^{30}$. In this emotional process, performative language expresses many practices and actions, which are considered discursive practices. The language inside an action refers to how people create, transform and reframe a phenomenon. Thus, the language and discourses tell the reality of the world ${ }^{1,9,10}$.

The association between oral health and beauty was present in the meaning of oral health and, therefore, we create the interpretative repertoire named Oral Health is a beautiful smile and a well-being condition. Sometimes, we can understand the meaning of oral health, by older people's perspective, as a reflection of beauty and aesthetic sense of harmony amongst aging, health and happiness. The link between these situations might have a beautiful smile as an indication of the importance attributed to oral health. Moreover, the aesthetic sense appears to be related to the comparison with the group and with the generation to which these older adults belong.

The concern by older people about their aesthetic situation was directly associated with the 
appearance of their mouth, teeth and lips. The literature corroborates this fact, as it shows that a negative perception is influenced by the unpleasant appearance of the teeth. Dissatisfaction with the staining of the teeth occupies a prominent position in this context ${ }^{20,31}$. Furthermore, satisfaction with dental treatment creates a subjective dental well-being ${ }^{29}$.

'Hum... my teeth were spaced out and large... then, there is no beautiful smile, is there?... and it is also ugly... this is something that bothers a lot... anyway... within what I saw and know... according to my age, I'm doing very well with this cute smile (laughs), I'm seventy-five years old' (Speech by participant $14 ; 75$ years old).

The satisfaction with aesthetic was implicitly associated with the comparison to the self-condition among other older people. Feeling good and dental well-being is an indication of the positive attributes and expectations presented by conversations and narratives that older people develop in his/her life $\mathrm{e}^{28,29,31}$. It is noteworthy that to an older people the personality will influence the concept and meaning regarding oral health ${ }^{32}$.

The subjectivity present in the narratives allowed us to understand that feeling good can be associated with the satisfaction of the oral health condition. A person needs to experience aspects that provide him with conditions to live well in society such as the following: the ability to communicate; an aesthetically socially acceptable look; absence of disorders and pain; good nutrition; and dental well-being ${ }^{1,26}$. Oral health is an essential component of the older people's life.

The 'nerve' is the part of the gum that goes underneath the denture... in the gum... I extracted the teeth, and then this 'nerve' remained down here (the interviewee points a finger at the lower alveolar ridge)... after I removed the teeth, I was more satisfied. Wow... on the top and bottom... hum... thank God I do not feel anything... nothing... I have no more teeth ((laughs))... it was about five years ago when I removed the rest of the teeth... and now I do not feel any pain. (Speech by participant 6; 70 years old).

The satisfaction after the serial extraction of teeth and the successful adaptation to dentures, leads us to comprehend that the suffering experienced in the past from dental problems possibly created a meaning of oral health in association with satisfaction and positive resilience. Thus, the terms present in the excerpt indicate the idea of continuity and life improvement after the removal of the cause of dissatisfaction. A disease is experienced as a discomfort characterized by pain, dizziness, nausea, cramps and feelings of anxiety, distress and palpitations, amongst others ${ }^{33}$. Alternatively, health is experienced as feeling well and no distress ${ }^{33}$. People enact their health and illness and endow it with meaning ${ }^{34}$. Feeling of tranquillity indicates the sense of being dental healthy.

Suffering appears as a substantial issue to comprehend oral health meanings. Facing the complex subjectivity behind suffering, we constructed another representative repertory named Oral health is deal with pain and suffering. Deal with pain can be associated with the ability to be resilient. Conversely, suffering, toward resilience, might be the trigger for a reconstruction of values about certain situations and the reconstruction of realities. Sometimes a person's feeling of pain and suffering indicate differences between their expectations and real perceptions of oral health ${ }^{35}$. Reality of pain and suffering do not just exist out there waiting to be discovered, it is constantly created by individuals who act in and toward their social environment ${ }^{34}$.

The reconstruction of values, by means of feeling pain in the past, can guide new attitudes and build new concepts for looking at the world and promoting health. In a certain way, this reconstruction must be perceived and observed by health professionals when assisting and treating older people $\mathrm{e}^{24}$. For older people, resilience helps to deal with uncomfortable situations. Older people that suffered in the past from something related to oral health, brings emotions and feelings that provide the construction of other meanings regarding oral health. Mouth pain and distress have a psychosocial impact in older adults' lives, which creates a sensitive topic to be disclosure ${ }^{23}$. Hence, suffering is inherent to dental treatment because it is legitimated as part of their life narratives ${ }^{7}$. Therefore, resigning means accepting their current oral health condition after suffering. Subjective experiences, as pain, are more common for older people and resilience might be associated with the acceptance of tooth loss in older people $\mathrm{e}^{7,36}$. Resignation and lack of hope are important issues reported by older Brazilian regarding their oral health condition ${ }^{37}$.

Events experienced in various historical and cultural processes of life can create connections between the subjectivity and the scientific object in focus, and this fact emphasizes the need for health education over treatment to empower older people ${ }^{10,38}$. Metaphorical expressions, which were provided with emotions, were evident in the performative languages present in the narratives. One participant said as far as I remember, I suf- 
fered a lot of tooth pain... and I took even medicines that 'burned my mouth'... but that is ok... causing pain... oh, my god! [...].

Pain is a symptom directly related to suffering. However, this happened in a period of life with intense suffering that stayed in the past, but still make sense in the present. These older people were young in a period of the Brazilian health policy where older people's rights did not exist. This fact appears in the narratives because the studied group shared similar experiences of suffering and same historic Brazilian policies in relation to dental care. Suffering might have allowed these participants to construct certain senses that are indicated in the interpersonal relationships. Older people, by comparing the past with the present and through self-care and positive self-perception, have shown that a 'dental-well-being' makes them satisfied with their health and life.

This study is one proposal for older people narrative interpretation. Using oral health as an aspect of analysis of the health of older people, helped us to understand the dialogical process of construction of the diverse meanings of health attributed by older people users of a health system grounded in the model of primary health care. This process of construction occurs parallel to life's history, behaviours and subjectivity in the complex path between health and disease in the search for satisfaction and well-being.

\section{Collaborators}

AF Bulgarelli, participated on the conception, planning, data collect, analysis, interpretation and writing of the work. FCM Zacharias participated on the interpretation and writing of the work. SF Mestriner participated on the analysis, interpretation and writing of the work. IC Pinto participated on the conception, planning, analysis, interpretation and writing of the work.
The results of this research have some limitations. We interviewed only independent, active and socialized older people who have access to primary healthcare services by means of SUS. Even living in vulnerability they did not bring to us a discourse of frail, dependent and not active older people. However, this study provides one of the several ways to study the meaning attributed to oral health by older people. The agreement of the involved researchers acknowledges the reliability of the result of this research. In this process, some initiatives were followed, such as constant exchanges of views and information culminating in consensual interpretations; checking the impressions obtained in the fieldwork with older people and joint examination of the final product of the research.

It was possible to comprehend that resilience, dental pain in the past, oral health considered as general health, oral hygiene, and valuing a beautiful smile constitute a framework of possible meanings assigned to oral health by older people. The proposal of this research explored some meanings of oral health and might be a device to comprehend the interpretative repertoires present in older people narratives. The present study suggests the development of new researches to associate the historical, social and cultural context to the meanings attribute to older people regarding their oral health. This study constructed some scientific knowledge to enrich our eye, actions and approach to the older people oral health.

\section{References}

1. Bulgarelli AF, Lorenzi CG, Silva RC, Mestriner SF, Villa TC, Pinto IC. Primary healthcare and the construction of meanings of oral health: a social constructionist interpretation of discourses of the elderly [Atenção primária à saúde e a construção de sentidos para a saúde bucal: leitura construcionista social sobre discursos de idosos]. Cien Saude Coletiva 2012; 17(8):2053-2062.

2. Martins AB, Santos CM, Marchi RJ, Hilgert JB, Hugo FN, Padilha DM. Resilience and self-perceived oral health: a hierarchical approach. J Am Geriat Soc 2011; 59(4):725-731.

3. Bakhtin M. The Dialogic Imagination: four essays. Austin: University of Texas Press; 1981.

4. Costa ALS, Maximiliano LPS. Narratives of family members on the suicide of older adults in an Amazonian metropolis. Rev Saude Publica 2017; 51:121.

5. Geib LTC. Social determinants of health in the elderly. Cien Saude Colet 2012; 17(1):123-133 
6. Silva DD, Held RB, Torres SVS, Sousa MLR, Neri AL, Antunes JLF Self perceived oral health and associated factors among older people in Campinas Southeastern Brazil, 2008-2009. Rev Saude Publica 2011; 45(6):1145-1153.

7. Camargo-Borges C, Mishima S. A Relational Responsibility as a Useful Tool to Community Participation in Primary Health Care. Saude Soc 2009; 18(1):29-41.

8. Gergen KJ. An invitation to social construction. Washington: Sage; 2009.

9. Potter J. Representing reality. Discourse rhetoric, and social construction. London: Sage; 1996.

10. Burr V. An introduction to social constructionism. London: Routledge; 2003.

11. Smith B, Mcgannon KR. Developing rigor in qualitative research: Problems and opportunities within sport and exercise psychology. International Review of Sport and Exercise Psychology 2017; (10):1-21.

12. Davidson C. Transcription: Imperatives for qualitative research. International Journal of Qualitative Methods 2009; 8(2):35-52.

13. Souza Minayo MC. Sampling and saturation in qualitative research: consensuses and controversies. Revista Pesquisa Qualitativa 2017; 1(5).

14. Folstein MF, Folstein SE, McHugh PR. A practical method for grading the cognitive state of patients for the clinician. J Psychiatr Res 1975; 12(1):189-198.

15. Nes FV, Abma T, Jonsson H, Deeg D. Language differences in qualitative research: is meaning lost in translation? Eur J Ageing 2010; 7(4):313-316.

16. Chen HY, Boore JR. Translation and back-translation in qualitative nursing research: methodological review. Journal Clin Nurs 2010; 19(1-2):234-239.

17. Oliveira RFRD, Souza JGS, Haikal DSA, Ferreira EF, Martins MEDB. Equidade no uso de serviços odontológicos provenientes do SUS entre idosos: estudo de base populacional. Cien Saude Colet 2016; 21(11):3509-3523.

18. Carvalho C, Manso AC, Escoval A, Salvado F, Nunes C. Autopercepção da saúde bucal em idosos de uma população urbana em Lisboa, Portugal. Rev Saude Publica 2016; 50:53.

19. Silva DD, Held RB, Torres SVS, Sousa MLR, Neri AL, Antunes JLF. Autopercepção da saúde bucal em idosos e fatores associados em Campinas, SP, 2008-2009. Rev Saude Publica 2011; 45(6):1145-1153.

20. Mota LB, Aguiar AC, Caldas CP. The Family Health Strategy and healthcare for older people: experiences in three Brazilian cities. Cad Saude Publica 2011; 27(4):779-786.

21. Brondani MA, MacEntee MI, Bryant SR, O’Neill B. Using Written Vignettes in Focus Groups Among Older Adults to Discuss Oral Health as a Sensitive Topic. Qual Health Res 2008; 18(8):1145-1153.

22. Antunes JLF, Narvai PC. Políticas de saúde bucal no Brasil e seu impacto sobre as desigualdades em saúde. Rev Saude Publica 2010; 44(2):360-365

23. Pucca Júnior GA. A política nacional de saúde bucal como demanda social. Cien Saude Colet 2006; 11(1):243-246.

24. Hurst G, Wilson P, Dickinson A. Older people: how do they find out about their health? A pilot study. $\mathrm{Br} \mathrm{J}$ Community Nur 2013; 7(5):224-230.
25. Silveira Filho AD, Moysés SJ, Kusma SZ, Moysés ST. Potencial de efetividade das estratégias de promoção da saúde bucal na atenção primária à saúde: estudo comparativo entre capitais e regiões do Brasil. Revista Brasileira de Epidemiologia 2016; 19(4):851-865.

26. MacEntee MI, Hole R, Stolar E. The significance of the mouth in old age. Soc Sci Med 2007; 45(9):1449-1458.

27. Gregory J, Gibson B, Robinson PG. Variation and change in the meaning of oral health related quality of life: a 'grounded' systems approach. Soc Sci Med 2005; 60(8):1859-1868.

28. Brondani MA, Bryant SR, MacEntee MI. Elders assessment of an evolving model of oral health. Gerodontology 2007; 24(4):189-195.

29. Halvari AEM, Halvari H, Bjørnebekk G, Deci EL. Oral health and dental well-being: testing a self-determination theory model. Journal of Applied Social Psychology 2013; 43(2):275-292.

30. Marcellini F. Health perception of elderly people: the results of a longitudinal study. Arch Gerontol Geriatr Suppl 2012; 8:181-189.

31. Tin-Oo MM, Saddki N, Hassan N. Factors influencing patient satisfaction with dental appearance and treatments they desire to improve aesthetics. BioMed Central Oral Health 2011; 11(6):1-8.

32. Thomson WM, Caspi A, Poulton R, Moffitt TE, Broadbent J. M. Personality and oral health. Eur J Oral Sci 2011; 119(5):366-372.

33. Borreani E, Jones K, Scambler S, Gallagher JE. Informing the debate on oral health care for older people: a qualitative study of older people's views on oral health and oral health care. Gerodontology 2010; 27(1):11-18.

34. Conrad P, Barker KK. The Social Construction of Illness: Key Insights and Policy Implications. J Health Soc Behavior 2010; 51(6):67-79.

35. Armfield JM, Enkling N, Wolf CA, Ramsier CA. Dental fear and satisfaction with dental services in Switzerland. J Public Health Dentistr 2014; 74(1):57-63.

36. Slade GD, Sanders AE. The Paradox of Better Subjective Oral Health in Older Age. J Dental Res 2011; 90(11):1279-1285.

37. Haikal DSA, Paula AMBD, Martins AMEDB, Moreira AN, Ferreira EF. Self-perception of oral health and impact on quality of life among the elderly: a quantitative-qualitative approach. Cien Saude Colet 2011; 16(7):3317-3329.

38. Goel P, Singh K, Kaur A, Verma M. Oral healthcare for elderly: Identifying the needs and feasible strategies for service provision. Indian J Dent Res 2006; 17(1):11-21.

Article submitted 05/02/2018

Approved 23/06/2018

Final version submitted 25/06/2018 